\title{
Effect of Urban Centre Growth on Vegetation Cover: A Case Study of Ebony State, South-eastern, Nigeria
}

\author{
Diagi Bridget Edewede ${ }^{1^{*}}$, Edokpa David Onojiede ${ }^{2}$ Nwaerema Peace $^{1}$ \\ ${ }^{1}$ Department of Geography and Environmental Management, University of Port Harcourt, Port Harcourt, Nigeria \\ ${ }^{2}$ Department of Geography and Environmental Management, Rivers State University, Port Harcourt, Nigeria
}

Corresponding Author Email: edeoli@yahoo.com

https://doi.org/10.18280/eesrj.060201

Received: 16 March 2019

Accepted: 3 June 2019

\author{
Keywords: \\ built-up areas, effects, growth, urban \\ centre, vegetation cover
}

\begin{abstract}
Most cities around the world are experiencing growth as a result of increased economic activities. Worse hit will be the vegetation cover which has to pave way for this development to take place. Landsat imageries of 1984, 2000, 2007 and 2015 were analyzed using Erdas Imagine 9.2 and ArcGIS 10.2 tools for changes. Results indicate that vegetation cover lost as much as $48.4662 \%$ in the 31 years period the study covered. The reduction in vegetation cover was found to have been replaced majorly by increases in built-up areas. The built-up domain increased from 42074.39 hectares in 1984 to 212762.3 hectares in 2015 representing an increase of $35.8487 \%$. The R2 of 0.9708 shows that $98 \%$ of the vegetation loss in the study area was accounted for by increases in built-up areas. The study also revealed that the area was expanding at the rate of $13.0 \%$ yearly within the analysed period, while within the same period $44.95 \%$ representing $1.45 \%$ of vegetation cover was lost yearly. If this trend is allowed to continue, vegetation by 2025 shall be reduced by an additional $-23.49 \%$. Therefore, adequate measure must be put in place to lessen the rate at which vegetation cover is been exploited.
\end{abstract}

\section{INTRODUCTION}

The rapid development of major cities around the world has put pressure on the natural vegetation, which has led to a great decline in vegetation cover. This decline in the natural vegetation has led to losses of habitat and a decrease in species of animals that are indigenous to such environment. This loss is a great burden to the natural environment as well as economic and social wellbeing of the people whose livelihood is dependent on the natural resources. As the needs and desire of man continue to be on the increase, the demands for land are also increasing. Vegetation generally is a term that is used to describe the plant life of a region; most times it is referred to as the ground cover provided by plants, and is, by far, the most abundant biotic element of the biosphere. For the earth's environment, vegetation in its natural state constitutes the biologically richest ecosystems as its plays significant role in regional hydrology, carbon storage and the global climate interactions [1-3]. The benefits derived from vegetation by man are in multiple folds especially healthy and productive vegetation. Hence vegetation is seen as the lifeblood of human societies around the world [4]. However, the increasing demand for land by man for several activities of man's endeavours is creating a rapid decline on vegetation cover thereby creating in balance in the natural cover of the earth environment. A great number of these changes in the natural features of the earth surface have been greatly attributed to changes in population, urbanization, shifting cultivation, animal grazing. Ebonyi State has also witness its share of this rapid uncontrolled expansion with huge adverse implication on its vegetal cover. As vegetation is removed it gives way to the removal of biodiversity also which implies destruction of wildlife habitat, depreciation or extinction of genetic pool, loss of food and medicinal herbs, encouraging desertification, pollution, erosion and drought $[5,6]$. The long term effect of depleting vegetation has far reaching consequences on man and the natural environment as a whole. It has been noted that deforestation or vegetation loss account for about 1.6 billion metric tons of carbon to the atmosphere per year thereby, rising atmospheric carbon dioxide $\left(\mathrm{CO}_{2}\right)$ which serves as a major contributor to atmospheric greenhouse effect [7]. These greenhouse gases tend to absorb and re-emit radiation in turn, warming the atmosphere, or increasing the average global temperature of the atmosphere near the earth surface [8]. The vegetation of the study area used to be home to many types of animals ranging from grass-cutters, squirrels, rabbits, snails, hawk, different species of monkeys, different species of birds, reptiles and a whole lot of other animals. Unfortunately, this is not the case as at today because of the continuous uncontrolled human activities in the area which has impacted seriously and negatively on the vegetation of the area, the area is now known to have less vegetation. The flora as well as the fauna of the area is facing extinction because of loss of habitats. Many notable animals known to have existed in the area in the past have disappeared recently due to increased human impact on the ecosystem. One of the most effective ways to study changes in the natural environment is the use of past images paired with more recent images in the detection of changes in the landscape over a period of time with the view of analyzing its effects on phenomena $[9,10]$. This is because the ability to detect changes in earth surface features using remote sensing datasets gives a clearer and better view in understanding the 
changes that have taken place in the natural features of the earth surface such as vegetation, water bodies etc. Change detection plays a vital role in presence of either large-scale evolution of areas at large time-scale or sharp sudden change after the occurrence of a natural hazard, particularly when urban environment with dense built-up areas is under consideration [11]. Change detection is a very significant area in research as the time and precision of changes observed on the land surface allows for an in-depth comprehension of the interactions between man and the natural phenomena and can provide guidance in managing land and resources [12]. Using satellite imagery has been a very popular means of studying changes in the environment since the early $80 \mathrm{~s}$, as it has helped in creating improvement in the assessment of changes in the environment. Satellite imagery has been applied in several remote sensing applications including forestry management [13], and regional mapping/ planning $[14,15]$ and also to assist health researchers in the management, planning, monitoring and evaluation for disease in an area [16]. Previous researches have shown nearly the same characteristics in trend [17-20] and [21] which have showed that as urban cities expand vegetation cover is been reduced. It is therefore important that regular monitoring of the natural environment be carried out to ascertain the rate at which rapid development of cities is impacting on vegetation cover especially bearing in mind its importance in maintaining the natural balance of the environment. This present study therefore, aims at assessing the rate at which vegetation is being depleted to give way to urban settlement and also provide relevant information to planning authorities to assists in making decisions that could quickly and easily mitigate the unfavorable effects of the changes on man and the environment in general.

\section{MATERIALS AND METHOD}

\subsection{The description of study area}

Ebonyi State in Southeastern Nigeria lies between the savannah belts and the rainforest. The southern and northern areas of the State is endowed with large quantity of palm trees. The most common vegetation in the State is tree shrubs. Vegetation in the State has a mixture of savannah and semitropical forest with agriculture being the main occupation of the people [22]. The area has been described as part of the low land rainforest region [23]. Ebonyi State (Figure 1) has a population of 2.1 million [24]. The State has a landmass of approximately 5,935 square kilometres. The State capital is located at Abakaliki and also the biggest city. The second biggest town in the state is Afikpo, located in the Southern border with Cross River State. Ebonyi State is a major producer of rice for the nation. Other notable crops cultivated in the State include: cassava, oil palm and groundnut. Ebonyi has several solid mineral resources, including lead, crude oil, and natural gas. The presence of these mineral resources spread across the State has greatly influence the development of more urban areas hence the decline in vegetation cover over time. In Ebonyi State, there has been an increase in the number of manufacturing and industrial sector in recent times, the State has several food processing factories which include rice mills, quarry factories and a fertilizer blending plant. The State also has one of the largest poultry in Nigeria and one of Nigeria's first cement factories. The influence of the many human activities that have characterized the area in the past few decades have greatly impacted on vegetation cover negatively.

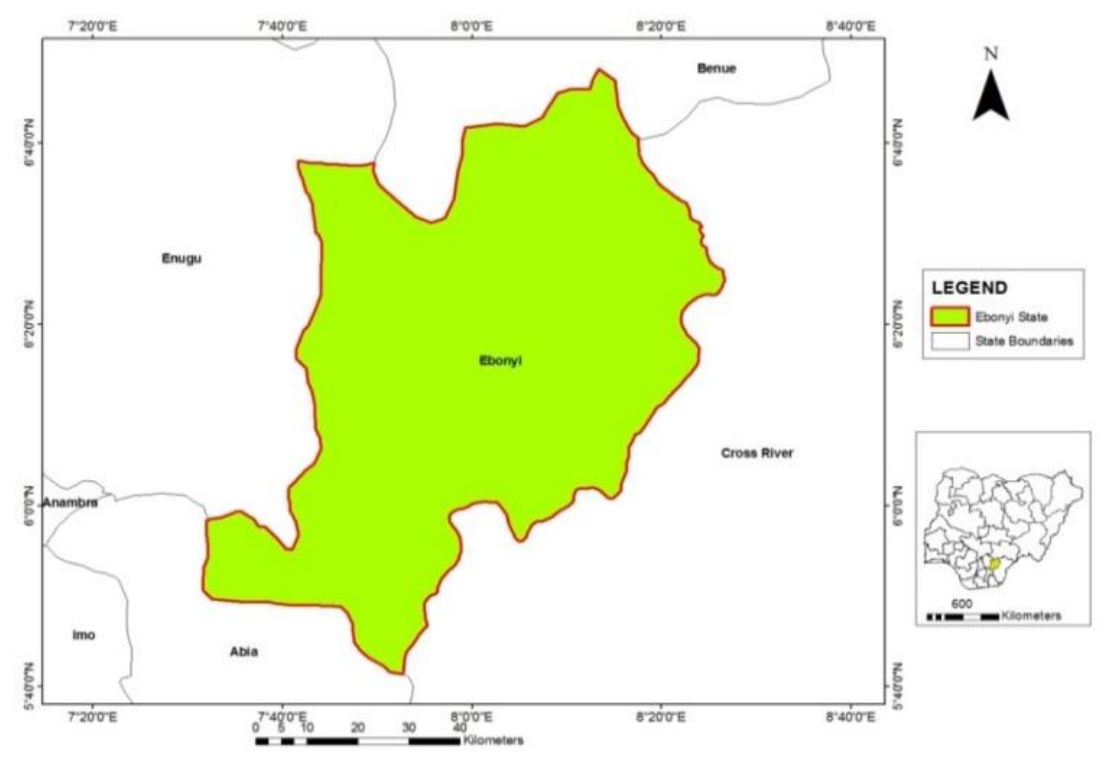

Figure 1. Map of Ebonyi State, Southeastern Nigeria

\subsection{Methods of data collection}

Landsat imageries of 1984 (MSS), 2000 (ETM+), 2007 (TM) and 2015 (TM) helped in the determination of the landuse/landcover classes. Supervised classification method was used to classify the imageries of each year into different type of landuse. The changes observed in the areas between the decades were computed using the classified imageries with areal extent. In this study, the post classification method was used because it allows the use of legends in details. In using post classification method, imageries from various archives in different year interval are classified and labeled separately. This method helped in discovering the changes in areas extents and also the rate of change observed over time. ERDAS Imagine 9.2 software was used for the analysis of the Landsat imageries, which include mosaicking, subsetting, 
layer stacking, and supervised classification of landuse into classes, ArcGIS 10.2 software was used to complement data processing and also for image enhancement. The use of ERDAS IMAGINE 9.2 software following the post classification method, helped in knowing the absolute area change and relative change of Landcover/landuse classes. To calculate the changes of each LULC classes to other LULC classes, LULC change matrix was done. Tables were drawn to show the change detection matrix that displayed the change of one LULC to the other. The negative sign on the tables shows that the landuse/landcover is in a state of decrement while the positive sign shows that there is an increment in LULC type. Calculations were done in hectares for the different types of landuse. Figure 2 shows the methodological flow chart of the study. The comparisons of the land cover statistics helped to identify changes in hectares/percentage, rate of change between 1984 and 2015. Percentage change to determine changes in built-up areas and vegetation classes for the period under study were extracted from the classified images in order to determine the spatial growth of the State and changes in vegetation cover. The percentage change between 1984 and 2015 was calculated with the assumption that the land area in 1984 was $100 \%$. This was also done for the extent and rate of vegetation cover over time. The mean statistic was used in this study to show the extent of changes yearly in both built-up areas and vegetation cover for the number of years covered for each epoch from 1984- 2015. While linear regression model is used in this study to model the actual relationship that exist between built up areas and the loss in vegetation cover over the 31 years period. The result helps to determine the overall extent of changes in the study area. Their expressions are as follows:

$$
\bar{x}=\sum_{\frac{i=1}{n}}^{n} x i
$$

where i runs from 1 to $\mathrm{n}$

The equation for linear regression is

$$
y=a+b x
$$

where

$$
b=\frac{n \sum x y-\left(\sum x\right)\left(\sum y\right)}{n \sum x^{2}-\left(\sum x\right)^{2}}
$$

and

$$
a=\frac{\sum y}{n}-\frac{b \sum x}{n}=\bar{y}-b \bar{x}
$$

$\mathrm{a}$ is the intercept; $\mathrm{b}$ the regression coefficient or slope; $\mathrm{y}=$ the actual vegetation cover values for each epoch (dependent variable);

$\mathrm{x}=$ the actual values of built up areas for each epoch; (independent variable)

$\bar{x}=$ the mean of built up areas; and

$\bar{y}=$ the mean of vegetation cover

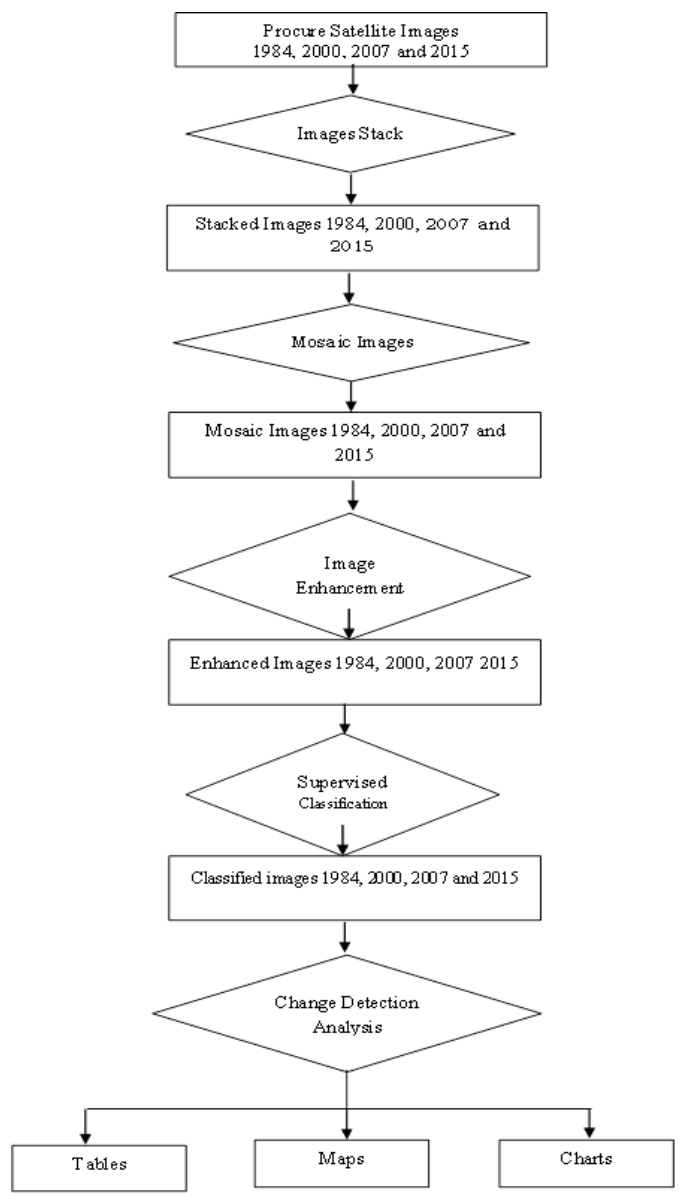

Figure 2. Methodological flow chart

\section{RESULTS AND DISCUSSION}

Results from analysis are presented in tables and graphs. The extent and rate of vegetation changes is shown on Table 1. Changes in extent of built up area within the study period

\begin{tabular}{|c|c|c|c|c|c|c|}
\hline & Year & Vegetation cover $(\mathrm{Ha})$ & \multicolumn{4}{|c|}{ Extent of change Average (rate of change) } \\
\hline & & & Differences (Ha) & $\begin{array}{c}\text { \% Increase (+) } \\
\text { Decrease (-) }\end{array}$ & Ha/year & $\%$ \\
\hline $1984-2000(16)$ & $\begin{array}{l}1984 \\
2000\end{array}$ & $\begin{array}{l}522555.04 \\
485704.55\end{array}$ & -36850.49 & -7.1 & -2303.155 & -0.44 \\
\hline $\begin{array}{c}2000-2007 \\
\text { (7) }\end{array}$ & $\begin{array}{l}2000 \\
2007\end{array}$ & $\begin{array}{l}485704.55 \\
462385.07\end{array}$ & -23319.48 & -4.8 & -3331.35 & -0.69 \\
\hline $\begin{array}{c}2007-2015 \\
(8)\end{array}$ & $\begin{array}{l}2007 \\
2015\end{array}$ & $\begin{array}{l}462385.07 \\
287647.09\end{array}$ & -174737.98 & -37.8 & -21842.2 & -4.7 \\
\hline $1984-2015(31)$ & $\begin{array}{l}1984 \\
2015\end{array}$ & $\begin{array}{l}522555.04 \\
287647.09\end{array}$ & -234907.95 & -44.95 & -7577.67 & -1.45 \\
\hline
\end{tabular}
is shown in Table 2. Classified Images of the study area is shown as maps on Figure 3.

Table 1. Extent of vegetation change, magnitude, trend, rate and direction 
Table 2. Extent of changes in built-up areas rate, Magnitude, direction 1984-2015

\begin{tabular}{|c|c|c|c|c|c|c|}
\hline \multirow[t]{2}{*}{ Period } & \multirow[t]{2}{*}{ Year } & \multirow[t]{2}{*}{ Built-up (Ha) } & \multicolumn{4}{|c|}{ Extent of change Average (rate of change) } \\
\hline & & & Differences (Ha) & $\%$ increase (+) Decrease (-) & Ha/year & $\%$ \\
\hline $1984-2000(16)$ & $\begin{array}{l}1984 \\
2000\end{array}$ & $\begin{array}{c}42074.39 \\
50599.6\end{array}$ & 8525.22 & 20.26 & 532.9 & 1.3 \\
\hline 2000-2007 (7) & $\begin{array}{l}2000 \\
2007 \\
\end{array}$ & $\begin{array}{c}50599.6 \\
55559.99 \\
\end{array}$ & 4960.38 & 9.80 & 708.63 & 1.4 \\
\hline $2007-2015(8)$ & $\begin{array}{l}2007 \\
2015\end{array}$ & $\begin{array}{l}55559.99 \\
212762.3\end{array}$ & 157202.31 & 73.89 & 19650.3 & 35.4 \\
\hline 1984-2015 (31) & $\begin{array}{l}1984 \\
2015\end{array}$ & $\begin{array}{l}42074.39 \\
212762.3 \\
\end{array}$ & 170687.91 & 405.68 & 5506.06 & 13.0 \\
\hline
\end{tabular}

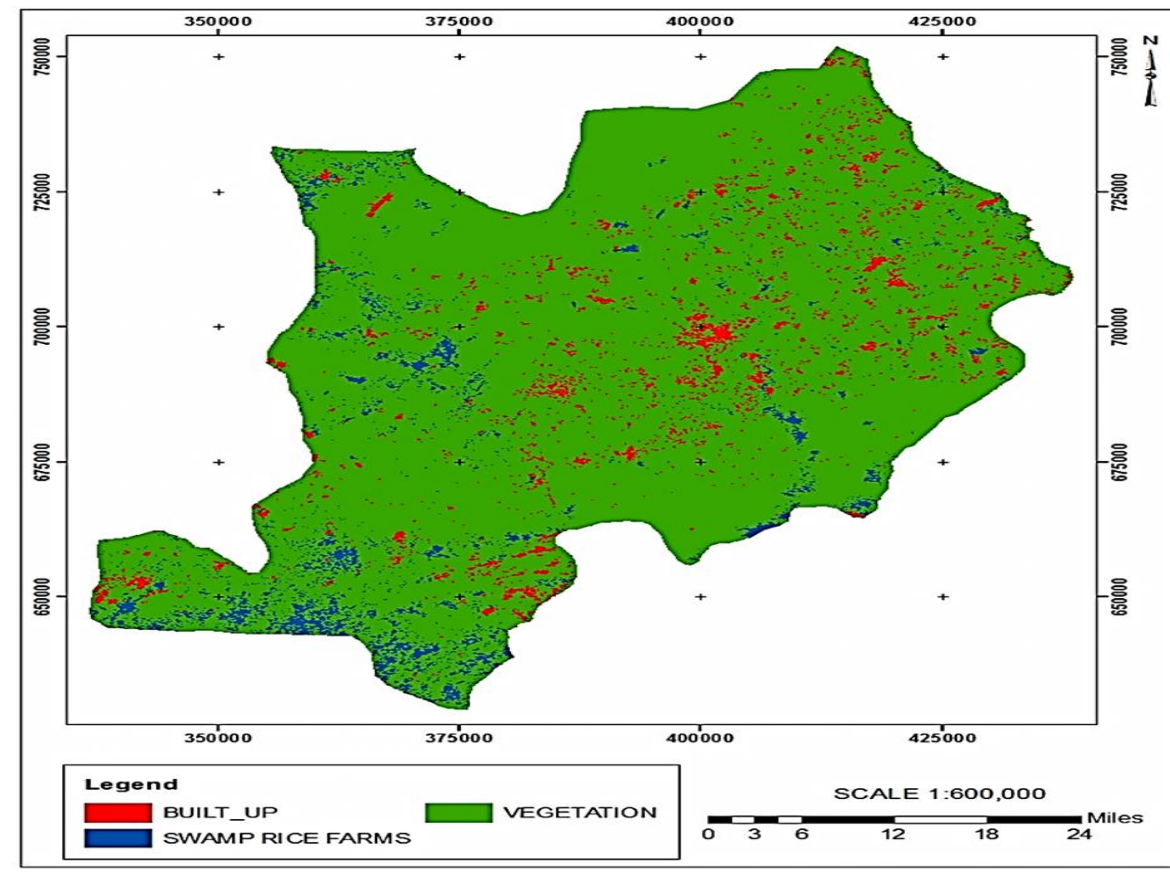

a. 1984

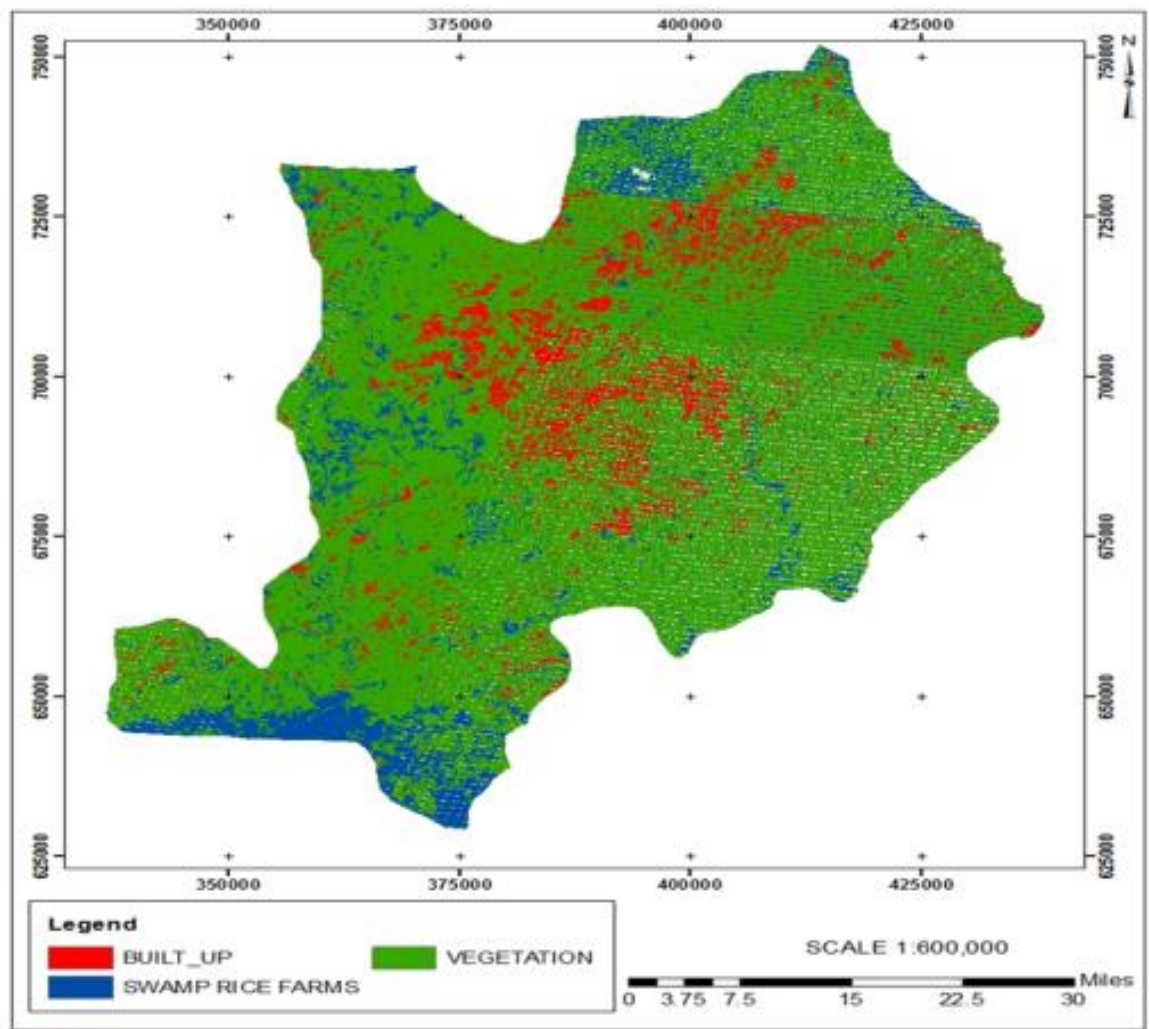

b. 2000 


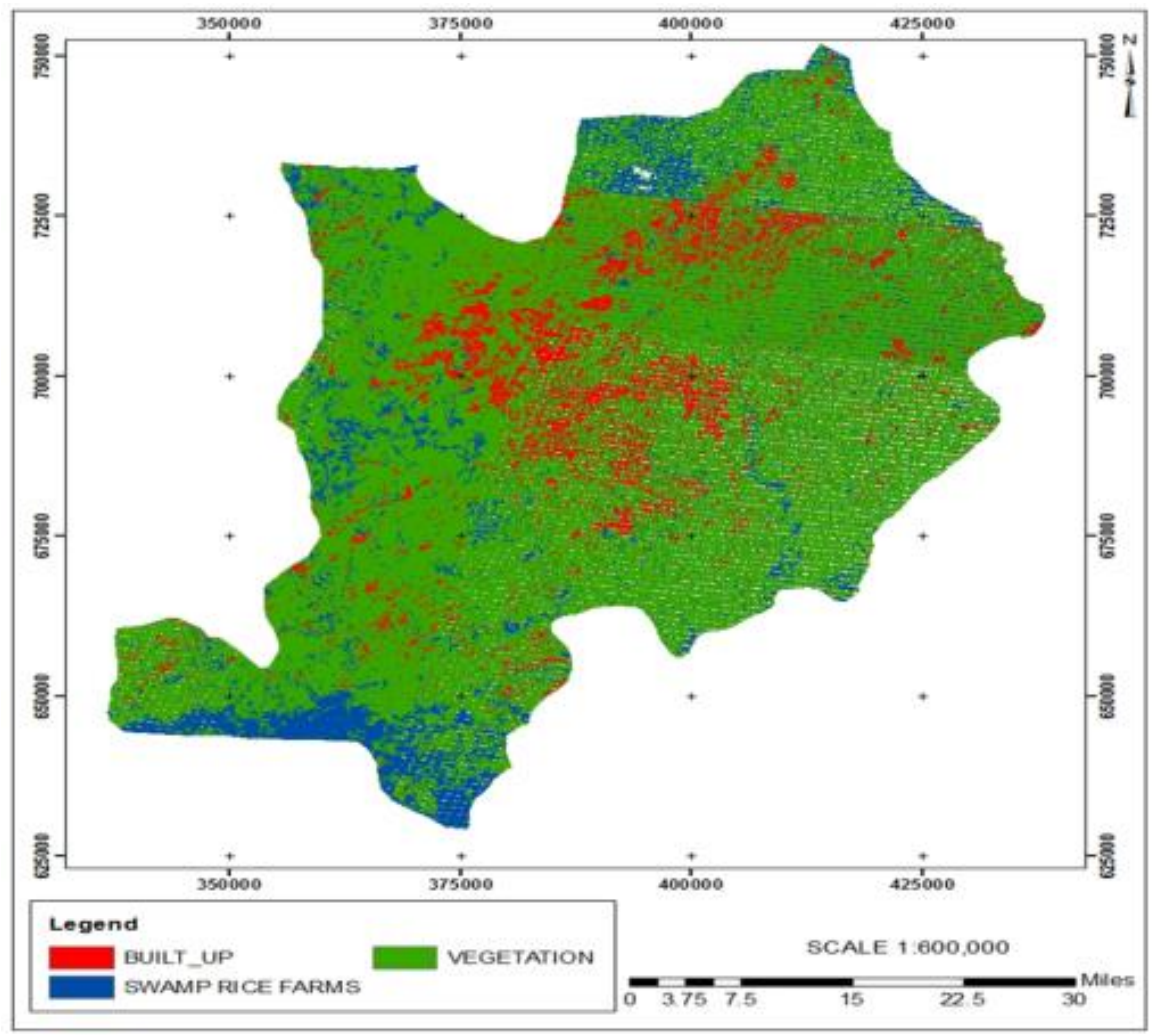

c. 2007

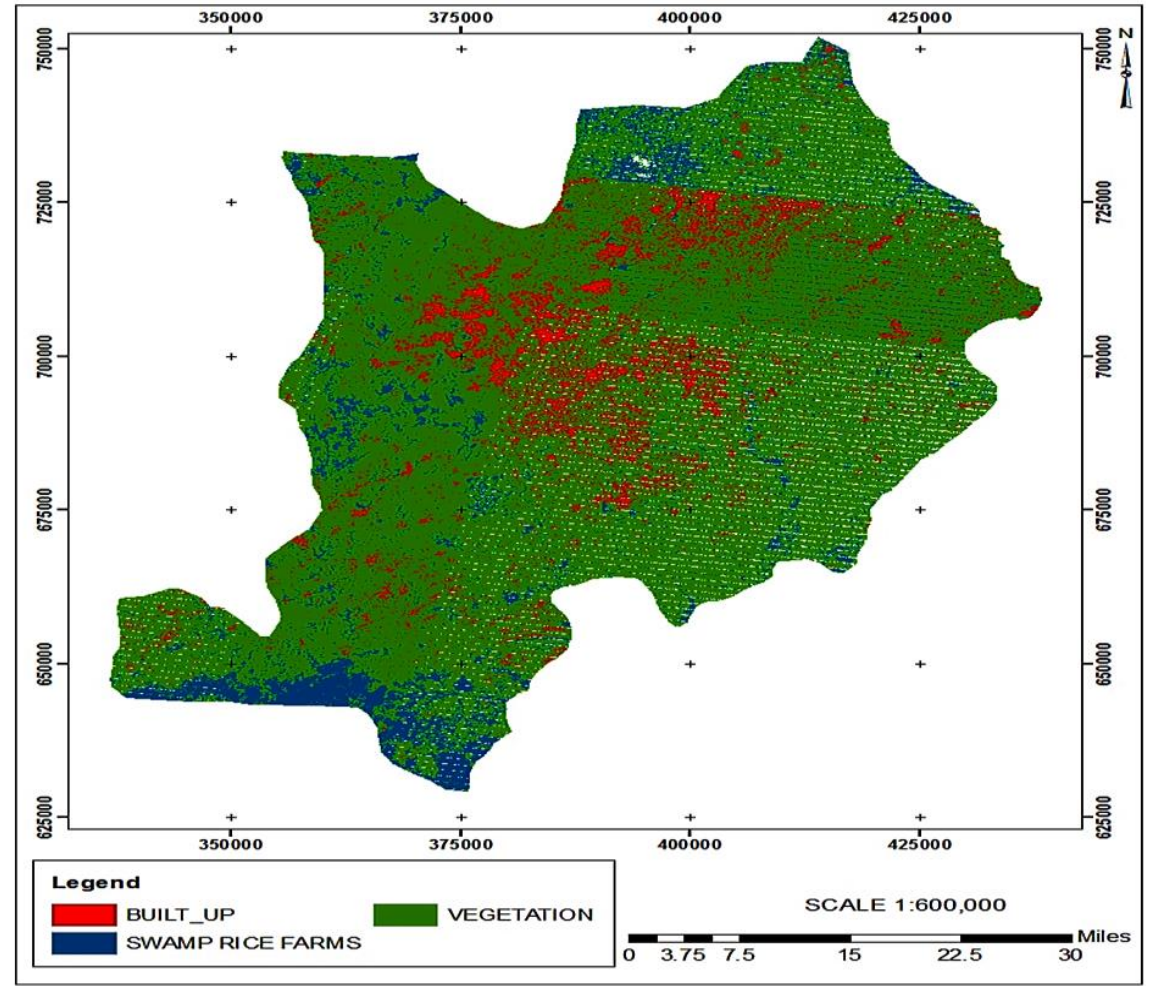

d. 2015

Figure 3. Classified map of the study area

\subsection{Extent and rate of vegetation change, 1984-2015}

By 1984 vegetation covered an area of 522555.04 hectares of the total landmass of the study area (Table 1). During the period of 1984 to 2000, vegetation loss was 36850.49 hectares with an annual change rate of 0.44 representing $7.1 \%$ decreases. This loss in vegetation cover was just 6 years after the State creation. The state has started to witness more flow of human and economic activities and as such more vegetation had to be cut down to accommodate the new status of the state as more built up areas emerged as shown on Table 2. The increases from built-up areas were from the losses recorded from vegetation cover (Table 2). From the study, it is very obvious that the new status of the study area has started having serious negative impact on vegetation cover, as vegetation further decreased by-23319.48 giving 
rise to more built-up areas which has by this time increased from 50599.6 hectares to 55559.99 hectares from 2000 to 2007 with annual change rate of $1.4 \%$. This is a clear indication of gradual expansion of the city to accommodate more economic as well as human activities. The gradual increase in built-up areas of the State by this time has started having a significant impact on vegetation cover. The period from 2007 to 2015 shows a major decrease in vegetation cover from 462385.07 hectares to 28764.09 hectares representing $-174737.98(-37.8 \%)$ decreases with an annual rate of change of $-4.7 \%$. During this period, built-up areas increased by 157202.31 hectares representing $73.89 \%$ with an annual rate of change of $35.4 \%$ which is the highest changes observed through -out the study period). This change in the vegetation cover of the State has shown how greatly man has exploited vegetation to meet his daily needs without consideration for the natural environment as more vegetation were destroyed to give way for more built up areas.

\subsubsection{Extent and rate of changes in built-up areas, 1984-2015}

The study reveals that within the 31 years of the study period, (1984-2015) built up area increased from 42074.39 hectares to 212762.3 hectares representing $405.68 \%$ increase. Growth rate annually was $13.0 \%$. The period from 2007 to 2015 shows a major decrease in vegetation cover from 462385.07 hectares to 28764.09 hectares representing $174737.98(-37.8 \%)$ decreases with an annual rate of change of $-4.7 \%$ (Table1). During this period, built-up areas increased by 157202.31 hectares representing $73.89 \%$ with an annual rate of change of $35.4 \%$ which is the highest changes observed through-out the study period. This study has shown that the natural vegetation of Ebonyi has greatly decline due to urbanization activities. The result on Table 2, indicate that built-up areas in Ebonyi State increased from 42074.39 hectares in 1984 to 212762.3 hectares in 2015 representing a percentage increase of 35.85. However, vegetation cover lost as much as $48.47 \%$ in the 31 years period the study covered. The direction of change was basically losses from vegetation cover to more built-up areas. This study has revealed that rapid urbanization has put so much pressure on vegetation as a result of great exploitation by man. This demand for space by man has increase the problem of deforestation there by living the environment with little or no protection which has led to flooding and other associated problems being experience at present in the study area. This is a clear indication of how insignificant man's view of the importance of vegetation has become. The extent of changes observed in vegetation cover and built up areas of the study area from 1984-2015 is represented graphically in Figure 4

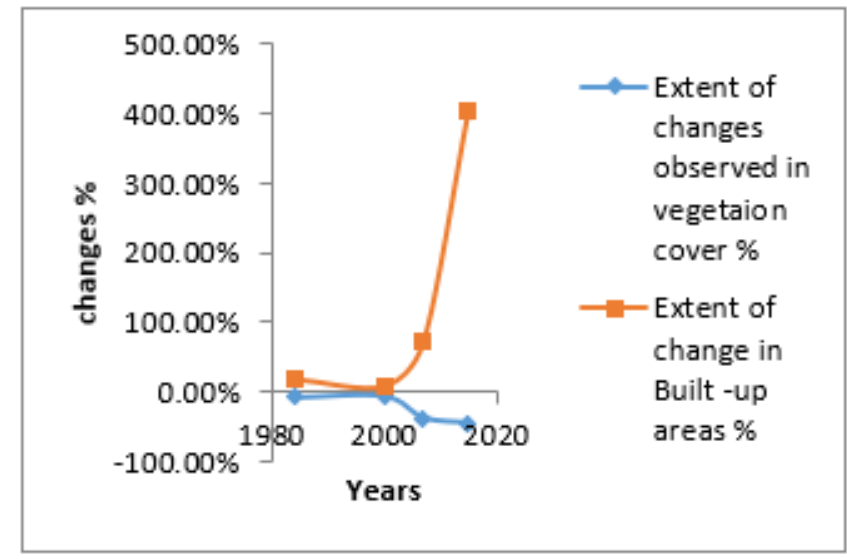

Figure 4. Extent of changes observed in vegetation covers and built up

The regression analysis carried out showed a positive correlation between built up areas and vegetation loss $(\mathrm{R}=$ $0.985) . R^{2}$ value of 0.9708 shows that $97 \%$ of the vegetation loss recorded over the study period was accounted for by built up areas Table 3. Therefore, it can be inferred that as built up areas increases there was a decrease in vegetation cover. The future change prediction was done to project the changes that will occur in the next 10 years (2025); the change in hectares was divided by the years under study to have the change per year in hectares and further multiplied by the number of years projected.

Projected change $(2025)=$ Change per year (in hectares) * projected years.

The study revealed that vegetation will further decrease by -23.49 if this trend continues as shown on Table 4. This analysis reveals that built-up area would continue to have serious impact on vegetation cover over time. It is obvious that vegetation will lose most of its area coverage to built-up area which may be due to continuous expansion of the State to accommodate more development. Therefore, conservation measures have to be adopted so as to develop programmes in order not to exceed the carrying capacity of the environment.

Table 3. Prediction model for built up and vegetation loss

\begin{tabular}{cccccc}
\hline Period & A (Intercept) & $\mathbf{b}($ Slope) & Regression line & $\mathbf{R}^{2}$ change & R (correlation coefficient) \\
$1984-2015$ & 552828.02 & $-1.2549 \mathrm{x}$ & $\mathrm{Y}=552828.02-1.2549 \mathrm{x}$ & 0.9708 & 0.985 \\
\hline
\end{tabular}

Table 4. Futures Changes in vegetation cover and built up areas 2015-2025

\begin{tabular}{cccccccc}
\hline $\begin{array}{c}\text { Land cover } \\
\text { classes }\end{array}$ & $\begin{array}{c}\text { Change in } \\
\text { hectares (1984- } \\
\mathbf{2 0 1 5 )}\end{array}$ & $\begin{array}{c}\text { \% Annual } \\
\text { Rate of } \\
\text { Changes }\end{array}$ & $\begin{array}{c}\text { Change per } \\
\text { year in } \\
\text { hectares }\end{array}$ & $\begin{array}{c}\text { Projected } \\
\text { Change }\end{array}$ & $\begin{array}{c}\text { Projected } \\
\text { change to } \\
\mathbf{2 0 2 5}\end{array}$ & $\begin{array}{c}\text { Status land } \\
\text { cover in 2025 }\end{array}$ & $\begin{array}{c}\text { Status of } \\
\text { land cover } \\
\mathbf{2 0 2 5}(\%)\end{array}$ \\
Built-up & 170687.91 & 13.086 & 5506.061 & 55060.61 & -12986.22 & -183674.13 & 17.06 \\
Vegetation & -234907.95 & 1.45 & -7577.675 & -75776.75 & 598331.79 & 363423.84 & -23.49 \\
\hline
\end{tabular}

\section{CONCLUSION}

The study shows that in the 31 years period of study (1984-2015), analysis revealed that built-up areas has greatly impacted on vegetation cover reducing it from 522555.04 hectares in 1984 to 287647.09 in 2015 representing (48.4662\%) reduction. The period $2007-2015$ recorded the highest decline in vegetation cover reducing it from 
462385.07 hectares to 28764.09 hectares representing $174737.98(-37.8 \%)$ decreases with an annual rate of change of $-4.7 \%$, it was also in this period that built-up areas appreciated with $35.4 \%$. Hence, it can be inferred that the built-up areas are taking up more of the vegetated land in the study area. The study shows that as more built-up areas were developed the vegetation cover decreased. If this trend continues, without a strong desire to control it, the State may become bare in no distance time. Based on these findings, the following recommendations were made that in order to preserve our vegetation more people should be encourage to plant trees so as to cushion the effects already created by deforestation to give way to urban area. Create more awareness on the danger of consistent depletion of vegetation by man for physical development.

\section{REFERENCES}

[1] Du, J., Shu, J., Yin, J., Yuan, X., Jiaerheng, A., Xiong, S., Liu, W. (2015). Analysis on spatio-temporal trends and drivers in vegetation growth during recent decades in Xinjiang, China. International Journal of Applied Earth Observation and Geo Information, 38: 216-228. https://doi.org/10.1016/j.jag.2015.01.006

[2] Forkel, M., Carvalhais, N., Verbesselt, J., Mahecha, M.D., Neigh, S.R.C., Reichstein, M. (2013). Trend change detection in NDVI time series: Effects of interannual variability and methodology. Remote Sensing, 5: 2113-2144. https://doi.org/10.3390/rs5052113

[3] Igbawua, T., Zhang, J., Chang, Q., Yao, F. (2016). Vegetation dynamics in relation with climate over Nigeria from 1982 to 2011. Environmental Earth Sciences, 75: 1-16. https://doi.org/10.1007/s12665-0155106-Z

[4] UNEP, IISD (Ed.). (2004). Exploring the links: Human well-being Poverty and Ecosystem Services. UNEP/IISD, Nairobi, Kenya, and Winnipeg, Manitoba, Canada.

[5] Adesina, A.F. (2005). Geo information and natural resources exploitation in Africa. A paper presented at the 4th Meeting of the committee on development information (CODI IV) held at Addis Ababa. Ethiopia; 2005.

[6] Ladipo, D. (2010). The State of Nigeria's Forests Research for Development Review. 4. http://r4dreview.org, accessed on 7 Mar. 2015.

[7] Akpu, B., Adamu, I.T., David, N.J., Bala, D. (2017). Geospatial analysis of urban expansion and its impact on vegetation cover in Kaduna metropolis. Nigeria Asian Journal of Environment \& Ecology, 3(2): 1-11. https://doi.org/10.9734/AJEE/2017/31149

[8] Botkin, B.D., Keller, A.D. (2005). Environmental Science: Earth as a Living Planet $2^{\text {nd }}$ Edition. John Wiley \& Sons Inc., Canada.

[9] Jensen, J.R. (2005). Introductory digital image processing: A remote sensing perspective. Geocarto International, 2(1). https://doi.org/10.1080/10106048709354084

[10] Chen, Y., Jing, L., Bo, Y., Shi, P., Zhang, S. (2007). Detection of coal fire location and change based on multitemporal thermal remotely sensed data and field measurements. International Journal of Remote Sensing,
28(15): $3173-3179$. https://doi.org/10.1080/01431160500444889

[11] Park, S.E., Yamaguchi, Y., Kim, D.J. (2013). Polarimetric SAR remote sensing of the 2011 Tohoku earthquake using ALOS/PALSAR. Remote Sensing of Environment, 132: 212-220. https://doi.org/10.1016/j.rse.2013.01.018

[12] Alqurashi, F.A., Kumar, L. (2013). Investigating the use of remote sensing and GIS techniques to detect land use and land cover change: A review. Advances in Remote Sensing, 2(2): 193-204. https://doi.org/10.4236/ars.2013.22022

[13] Forkuo, E.K., Frimpong, A. (2012). Analysis of forest cover change detection. International Journal of Remote Sensing Applications, 2(4): 82-92.

[14] Du, P., Liu, S., Gamba, P., Tan, K., Xia, J. (2012). Fusion of difference images for change detection over urban areas. IEEE Journal of Selected Topics in Applied Earth Observations and Remote Sensing, 5(4): 1076-1086. https://doi.org/10.1109/JSTARS.2012.2200879

[15] Hegazy, I.R., Kaloop, M.R. (2015). Monitoring urban growth and land use change detection with GIS and remote sensing techniques in Daqahlia governorate Egypt. International Journal of Sustainable Built Environment, 4(1): 117-124. https://doi.org/10.1016/j.ijsbe.2015.02.005

[16] Mwanret, G.D., Cyril, K.E., Moses, O., Hosea, S., Queen, O.S. (2019). The application of remote sensing and geographic information system in assessing probable tsetse flies habitats in Ikom LGA, Cross River State, Nigeria. Environmental and Earth Sciences Research Journal, 6(1): 19-23. https://doi.org/10.18280/eesrj.060103

[17] Lin, Y., Lin, Y., Wang, Y., Hong, N. (2008). Monitoring and predicting land use changes and the hydrology of the urbanized Paochiao watershed in Taiwan using remote sensing data, urban growth models and hydrological models sensors. Sensors (Basel), 8(2): 658-681. https://doi.org/10.3390/s8020658

[18] Torres-Vera, A.M., Prol-Ledesma, M.R., Garcia-Lopez, D. (2009). Three decades of land use variations in Mexico City. International Journal of Remote Sensing, 30(1):

117-138. https://doi.org/10.1080/01431160802261163

[19] Akpu, B. (2002). Potential of using remote sensing to assess actual land use deviation from Abuja master plan: A case study of wuse-1Abuja. Unpublished M. tech. project. Department of Geography, Federal University of Technology, Minna.

[20] Yuan, F. (2008). Land cover and environmental impact analysis in the great Mankota area of Minnesota using remote sensing and GIS modelling. International Journal of Remote Sensing, 29(4): 1169-1184. https://doi.org/10.1080/01431160701294703

[21] Akpu, B., Adamu, A. (2007). Pattern and explanations of encroachment into green areas in Zaria. Environ. Journal of Environmental Studies, 2(8): 44-53.

[22] Diagi, B.E. (2017). Climate variability, landcover changes and swamp rice cultivation in Ebonyi State, Nigeria. Ph.D. Thesis. Department of Geography and Environmental Management, Univ. of Port Harcourt Choba, Nigeria. 
[23] Ogbodo, E.N. (2013). Assessment and management strategies for the receding watersheds of Ebonyi State, Southeast Nigeria. Journal of Environment and Earth Science, 3(3): 18-26.
[24] National Population Commission

(NPC)

Population Census of Nigeria. Abuja. 